Nova Southeastern University

Florida

NOVA SOUTHEASTERN

UNIVERSITY

NSUWorks

Marine \& Environmental Sciences Faculty Articles Department of Marine and Environmental Sciences

8-16-2014

\title{
Enhanced Acidification of Global Coral Reefs Driven by Regional Biogeochemical Feedbacks
}

Tyler Cyronak

Southern Cross University - Lismore, Australia, tcyronak@nova.edu

Kai G. Schulz

Southern Cross University - Lismore, Australia

Isaac R. Santos

Southern Cross University - Lismore, Australia

Bradley D. Eyre

Southern Cross University - Lismore, Australia

Find out more information about Nova Southeastern University and the Halmos College of Natural Sciences and Oceanography.

Follow this and additional works at: https://nsuworks.nova.edu/occ_facarticles

Part of the Marine Biology Commons, and the Oceanography and Atmospheric Sciences and Meteorology Commons

\section{NSUWorks Citation}

Tyler Cyronak, Kai G. Schulz, Isaac R. Santos, and Bradley D. Eyre. 2014. Enhanced Acidification of Global Coral Reefs Driven by Regional Biogeochemical Feedbacks .Geophysical Research Letters , (15) : 5538 -5546. https://nsuworks.nova.edu/occ_facarticles/ 1040.

This Article is brought to you for free and open access by the Department of Marine and Environmental Sciences at NSUWorks. It has been accepted for inclusion in Marine \& Environmental Sciences Faculty Articles by an authorized administrator of NSUWorks. For more information, please contact nsuworks@nova.edu. 


\section{Geophysical Research Letters}

\section{RESEARCH LETTER}

10.1002/2014GL060849

Key Points:

- The $p \mathrm{CO}_{2}$ of coral reefs is rising more rapidly than in the open ocean

- Anthropogenic changes to regional

biogeochemical cycles may

be responsible

- Local actions may help to partially offset the acidification of coral reefs

Supporting Information:

- Readme

- Table S1

Correspondence to:

T. Cyronak,

tcyronak@gmail.com

\section{Citation:}

Cyronak, T., K. G. Schulz, I. R. Santos, and B. D. Eyre (2014), Enhanced acidification of global coral reefs driven by regional biogeochemical feedbacks, Geophys. Res. Lett., 41, 5538-5546, doi:10.1002/

2014 GL060849.

Received 11 JUN 2014 Accepted 17 JUL 2014 Accepted article online 19 JUL 2014 Published online 5 AUG 2014

\section{Enhanced acidification of global coral reefs driven by regional biogeochemical feedbacks}

\author{
Tyler Cyronak ${ }^{1}$, Kai G. Schulz ${ }^{1}$, Isaac R. Santos ${ }^{1}$, and Bradley D. Eyre ${ }^{1}$ \\ ${ }^{1}$ Centre for Coastal Biogeochemistry, Southern Cross University, Lismore, New South Wales, Australia
}

\begin{abstract}
Physical uptake of anthropogenic $\mathrm{CO}_{2}$ is the dominant driver of ocean acidification (OA) in the open ocean. Due to expected decreases in calcification and increased dissolution of $\mathrm{CaCO}_{3}$ framework, coral reefs are thought to be highly susceptible to OA. However, biogeochemical processes can influence the $p \mathrm{CO}_{2}$ and $\mathrm{pH}$ of coastal ecosystems on diel and seasonal time scales, potentially modifying the long-term effects of increasing atmospheric $\mathrm{CO}_{2}$. By compiling data from the literature and removing the effects of short-term variability, we show that the average $p \mathrm{CO}_{2}$ of coral reefs throughout the globe has increased $\sim 3.5$-fold faster than in the open ocean over the past 20 years. This rapid increase in $p \mathrm{CO}_{2}$ has the potential to enhance the acidification and predicted effects of $\mathrm{OA}$ on coral reef ecosystems. A simple model demonstrates that potential drivers of elevated $p \mathrm{CO}_{2}$ include additional anthropogenic disturbances beyond increasing global atmospheric $\mathrm{CO}_{2}$ such as enhanced nutrient and organic matter inputs.
\end{abstract}

\section{Introduction}

The conventional view of ocean acidification (OA) is based on the oceanic uptake of anthropogenic $\mathrm{CO}_{2}$ emissions and subsequent reduction in seawater $\mathrm{pH}$ [Doney et al., 2009; Bates and Dickson, 2012]. However, considering atmospheric $\mathrm{CO}_{2}$ as the sole driver may only apply to the open ocean as a number of additional anthropogenic perturbations can influence carbonate chemistry in coastal ecosystems [Andersson et al., 2013; Duarte et al., 2013]. Coral reefs exhibit some of the largest diel and seasonal seawater $p \mathrm{CO}_{2}$ and $\mathrm{pH}$ variability of coastal ecosystems, with $p \mathrm{CO}_{2}$ occasionally well above what is projected for the open ocean by the turn of the century due to anthropogenic $\mathrm{CO}_{2}$ emissions [Kayanne et al., 1995; Bates, 2002; Silverman et al., 2007; Anthony et al., 2011]. Multiple drivers are known to contribute to this variability including watershed inputs of nutrients and organic matter and community metabolism [Suzuki et al., 2001; Anthony et al., 2011; Duarte et al., 2013]. Unfortunately, no long-term monitoring stations analogous to those in open ocean surface waters [e.g., Doney et al., 2009; Friedrich et al., 2012; Bates et al., 2014] exist in coral reefs which would allow for the integration of long-term trends beyond diel and seasonal variability.

It is estimated that over $50 \%$ of coral reefs across the globe experience medium-high to very high humanrelated impacts from a combination of overfishing, nutrient inputs, pollutants, and other disturbances [Halpern et al., 2008]. These anthropogenic impacts are known to effect community level metabolic processes and could play an important and synergistic role in the acidification of coral reefs. Models indicate that the natural variability of coral reef seawater carbonate chemistry will be amplified by increasing atmospheric $\mathrm{CO}_{2}$ due to a decrease in seawater buffering capacity [Jury et al., 2013; Shaw et al., 2013]. Therefore, any anthropogenic perturbations to ecosystem level drivers of coral reef seawater carbonate chemistry could be equally important as increasing atmospheric $\mathrm{CO}_{2}$ in raising the average $p \mathrm{CO}_{2}$ of these ecosystems. A recent seasonal data set in a Bermuda coral reef implied that OA could be partially buffered by changes to coral reef metabolism [Andersson et al., 2013]. Here we use global observations integrated over at least one diel cycle and a simple model of coral reef metabolism to show that the average $\mathrm{pCO}_{2}$ of coral reefs has increased faster than open ocean $\mathrm{pCO}_{2}$, most likely due to local anthropogenic disturbances to the metabolic balance of coral reef ecosystems. This rapid increase in $\mathrm{pCO}_{2}$ has the potential to enhance the predicted effects of OA on coral reefs.

\section{Materials and Methods}

\subsection{Data Compilation}

Average diel $p \mathrm{CO}_{2}$ and $\mathrm{pH}$ values of coral reefs were compiled from the literature (Table $\mathrm{S} 1$ in the supporting information). Any study indicating a coral reef as the field site was used when measurements 

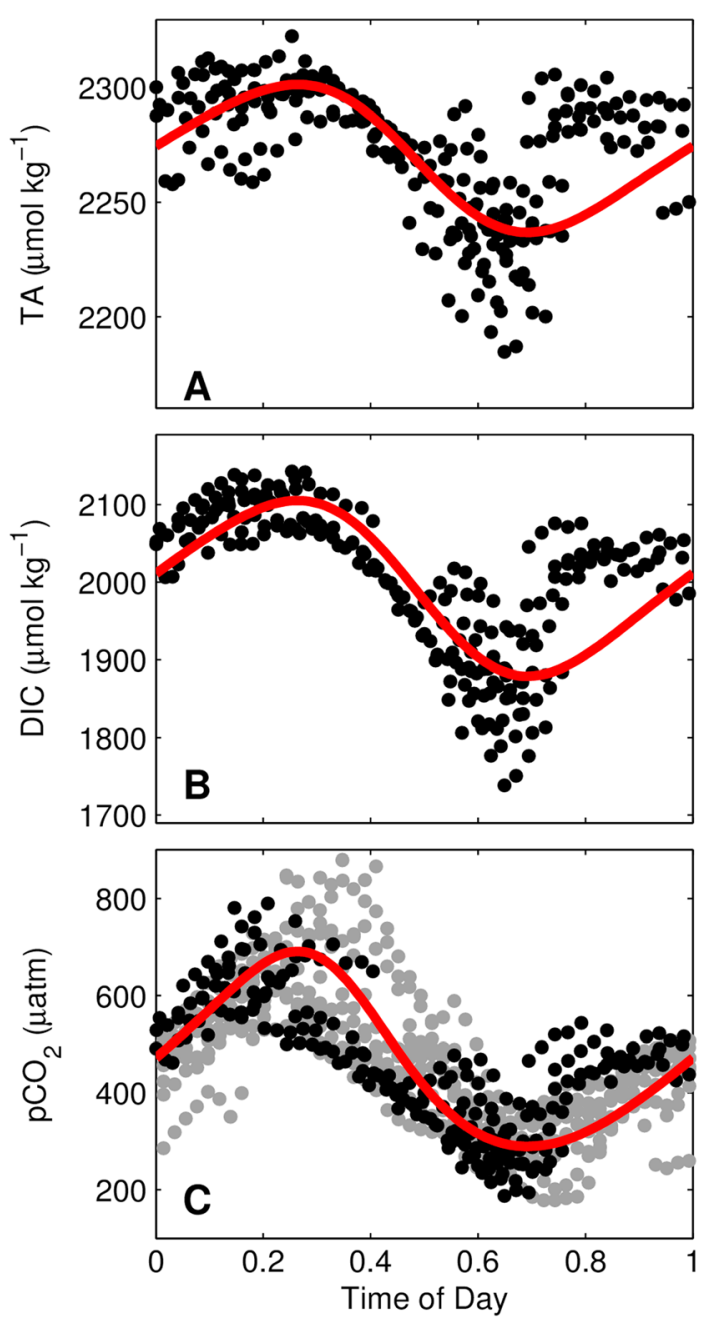

Figure 1. Model output under present-day conditions compared to measured parameters at Heron Island, GBR. (a) Total alkalinity (TA), (b) dissolved inorganic carbon (DIC), and (c) calculated (black dots) and measured (grey dots) $p \mathrm{CO}_{2}$ at Heron Island. The red lines represent the model run, including light- and biomass-dependent photosyntheses, respiration, calcification, calcium carbonate dissolution, and mixing (see section 2.2 for details). were taken over at least one diel cycle. In the case that seasonal measurements were taken, a yearly average is shown. When $\mathrm{CO}_{2}$ levels were reported as $\mathrm{fCO}_{2}$ in the original study, it was converted to $p \mathrm{CO}_{2}$ by multiplying by 1.003 , as this is the difference between fugacity and partial pressure of $\mathrm{CO}_{2}$ at typical in situ temperatures. In order to normalize $\mathrm{pH}$ to the total scale, 0.13 was subtracted from all values on the National Bureau of Standards (NBS) scale. The transformation of $\mathrm{pH}$ from NBS to total scale is supported by the observed trend, which is consistent with changes in $p \mathrm{CO}_{2}$ over the same time period. When averages were not available explicitly in the text of original publications, the graph digitation program GetData (v2.25) was used to extract data. Analysis of covariance was performed to determine the statistical difference between regressions using the MATLAB Statistical Toolbox.

\subsection{Model Description}

A model was developed to evaluate how changes to coral reef metabolism influence average $p \mathrm{CO}_{2}$ over a diel cycle. The model considers changes in dissolved inorganic carbon (DIC) and total alkalinity (TA) based on measurements made at Heron Island (Australia) [McMahon et al., 2013]. Diel changes in the concentrations of DIC and TA were driven by processes of photosynthesis (light and autotrophic biomass dependent), respiration (total biomass dependent), calcification (light and coral biomass dependent), $\mathrm{CaCO}_{3}$ dissolution (coral biomass dependent), and mixing of lagoon seawater with an open ocean end-member as

$$
\begin{aligned}
& \frac{d \mathrm{DIC}}{d t}=-B k_{p} \sin (\pi t)^{4}+(B+C) k_{r}-C k_{c} \sin (\pi t)^{4}+C k_{d}-k_{m}\left(\mathrm{DIC}-\mathrm{DIC}_{\text {oceanic }}\right) / 2 \\
& \frac{d \mathrm{TA}}{d t}=2\left(-C k_{c} \sin (\pi t)^{4}+C k_{d}\right)-k_{m}\left(\mathrm{TA}-\mathrm{TA}_{\text {oceanic }}\right) / 2
\end{aligned}
$$

with $B$ denoting the autotrophic biomass (expressed in $\mu \mathrm{mol} \mathrm{kg}{ }^{-1}$ ); $C$ denoting the coral biomass (expressed in $\left.\mu \mathrm{mol} \mathrm{kg}{ }^{-1}\right) ; \sin (\pi t)^{4}$ simulating the diurnal changes in light availability; $k_{p}, k_{r}, k_{c}, k_{d}$, and $k_{m}$ being the rate constants $\left(\mathrm{d}^{-1}\right)$ for photosynthesis, respiration, calcification, calcium carbonate dissolution, and mixing, respectively; and $\mathrm{DIC}_{\text {oceanic }}$ and $\mathrm{TA}_{\text {oceanic }}$ representing typical open ocean end-members for DIC and $T A$, set to 2000 and $2300 \mu \mathrm{mol} \mathrm{kg}^{-1}$, respectively. The latter value combination was chosen to represent modern oligotrophic open ocean $p \mathrm{CO}_{2}$ levels of about $400 \mu \mathrm{atm}$ at an observed salinity of 34 and a temperature of $26^{\circ} \mathrm{C}$. Autotrophic and coral biomass were set to identical levels, and then $k_{p}, k_{r}, k_{c}, k_{d r}$ and $k_{m}$ were tuned to fit observations of diurnal variability in $\mathrm{DIC}, \mathrm{TA}$, and $p \mathrm{CO}_{2}$ and the corresponding mean levels (Figure 1). 

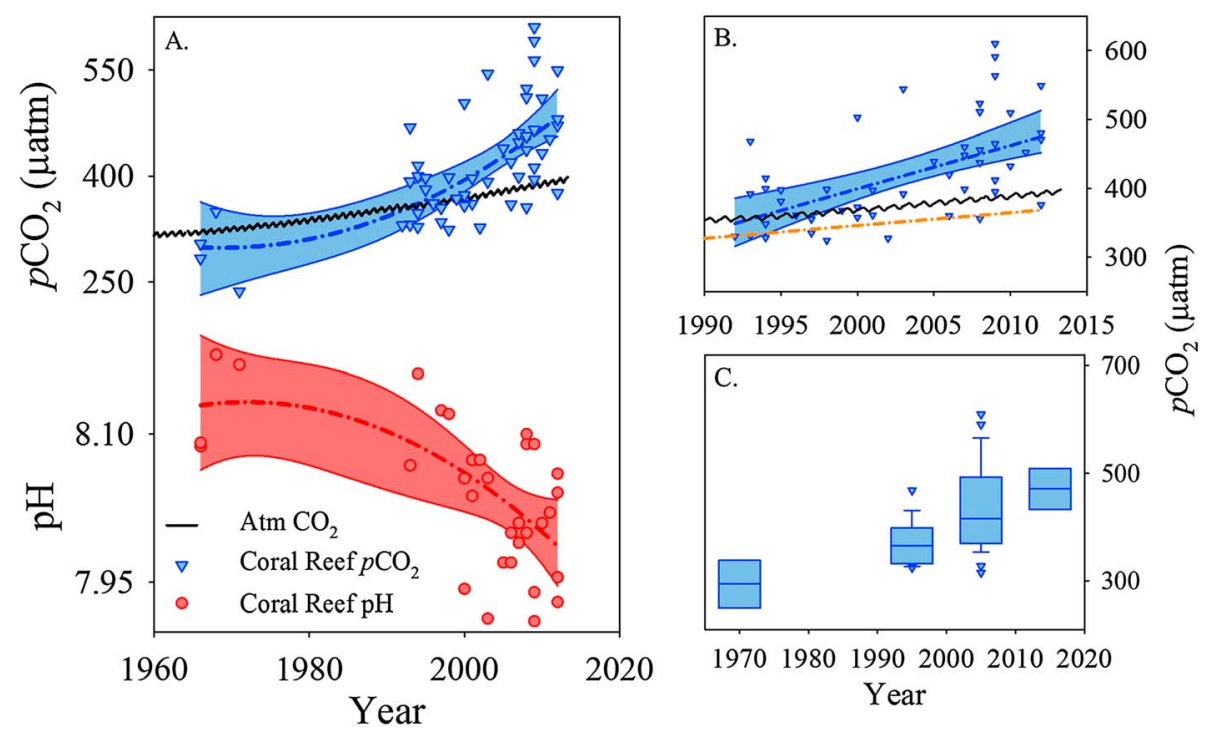

Figure 2. (a) Average coral reef $p \mathrm{CO}_{2}$ and $\mathrm{pH}$ values measured over at least one diel cycle. The studies ranged in length from 1 day to multiple years. Atmospheric $p \mathrm{CO}_{2}$ from Mauna Loa, Hawaii, is shown in black [Keeling et. al., 2001]. The dashed line represents a quadratic regression of the data, and the shaded region is the $95 \%$ confidence interval. (b) Linear regression of coral reef $p \mathrm{CO}_{2}$ levels since 1990 compared to a regression of open ocean surface water $p \mathrm{CO}_{2}$ (gold dashed line) [Doney et al., 2009] over the same time period. (c) Box diagram of the data binned into decades.

Note that initial biomass settings do not influence model results as the tuned rate constants scale accordingly. This also applies to the respiration term (equation (1)) which actually includes both autotrophic and heterotrophic components. Final parameter settings for modern Heron Island conditions were $400 \mu \mathrm{mol} \mathrm{kg}{ }^{-1}$ for $\mathrm{B}$ and $\mathrm{C}$ and $3,0.575,0.5,0.15$, and $2 \mathrm{~d}^{-1}$ for $k_{p}, k_{n} k_{C}, k_{d}$ and $k_{m}$, resulting in a ratio of photosynthesis to respiration of 0.98 , of calcification to calcium carbonate dissolution of 1.25 , and of photosynthesis to calcification of 6. These values are comparable to observations in Heron Island and other coral reef systems throughout the globe [Gattuso et al., 1999a; McMahon et al., 2013]. The differential equations (equations (1) and (2)) were solved numerically with the MATLAB ode45 solver [Shampine and Reichelt, 1997] until reaching steady state conditions. Carbonate chemistry speciation such as $\mathrm{pH}$ and $p \mathrm{CO}_{2}$ was calculated from modeled DIC and TA using the temperature-and salinity-dependent stoichiometric equilibrium constants for carbonic acid determined by Mehrbach et al. [1973] as refitted by Lueker et al. [2000]. To estimate the magnitude of the pure chemical effect of increasing open ocean $p \mathrm{CO}_{2}$ by $40 \mu$ atm during the last 20 years, the open ocean DIC end-member was reduced to $1978 \mu \mathrm{mol} \mathrm{kg}{ }^{1}$, corresponding to a $p \mathrm{CO}_{2}$ of $360 \mu \mathrm{atm}$.

\section{Results}

\subsection{A Global Trend of Rapidly Increasing Coral Reef $p \mathrm{CO}_{2}$}

Globally distributed observations show an increasing trend in the diel average of $p \mathrm{CO}_{2}$ in coral reefs since $1966\left(R^{2}=0.42, F=35.08, p<0.001\right.$, and $\left.n=51\right)$ (Figure 2a and Table S1 in the supporting information). The majority of values fall above the line of atmospheric $\mathrm{CO}_{2}$ indicating that increasing coral reef $p \mathrm{CO}_{2}$ is not being driven solely by atmospheric forcing. In the past $\sim 20$ years, open ocean surface $p \mathrm{CO}_{2}$ has increased at a rate of $\sim 1.9 \mu \mathrm{utm} \mathrm{yr}^{-1}$ [Doney et al., 2009; Bates and Dickson, 2012; Bates et al., 2014]. A linear regression of average coral reef $p \mathrm{CO}_{2}\left(R^{2}=0.34, F=23.13, p<0.001\right.$, and $\left.n=48\right)$ since 1992 indicates that the $p \mathrm{CO}_{2}$ of coral reefs has increased at a rate of $6.6 \pm 1.4 \mu \mathrm{atm} \mathrm{yr}^{-1}, \sim 3.5$ times faster than in the open ocean $\left(p<0.01\right.$ ) (Figure 2b). Between 1965 and 1975, the average $p \mathrm{CO}_{2}$ of all the coral reefs was $\sim 30 \mu$ atm below the average atmospheric $\mathrm{CO}_{2}$ level. In the ensuing decades, average coral reef $p \mathrm{CO}_{2}$ increased to $10 \mu \mathrm{atm}$ (1990-1999), $66 \mu \mathrm{atm}$ (2000-2009), and $73 \mu \mathrm{atm}$ (2010-2012) above average decadal atmospheric $\mathrm{CO}_{2}$ concentrations (Figure 2c). While we lack long-term uninterrupted observations in individual systems, the $p \mathrm{CO}_{2}$ trend in global coral reefs is consistent with the observations at One Tree Island, Great Barrier Reef (GBR) between 1968 and 2009, showing an $~ 70 \%$ increase in $p \mathrm{CO}_{2}$ (Table S1 in the supporting information) [Silverman et al., 2012]. 

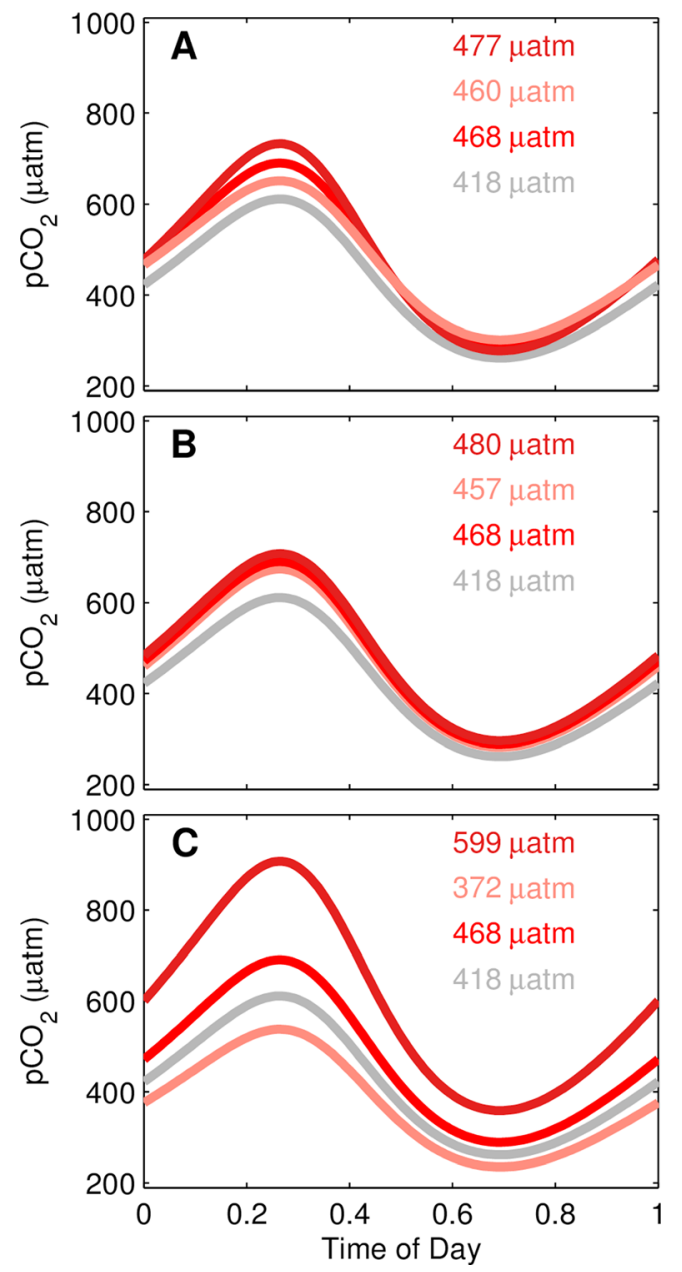

Figure 3. The impact of potential changes to various coral reef processes on the diel variability of seawater $p \mathrm{CO}_{2}$ at Heron Island. The intermediate red lines represent model runs fitting the present-day observations (compare Figure 1), while the light and dark red lines depict model runs with certain process rates decreased or increased, respectively. The grey lines represent a model run used to estimate the pure chemical effect (i.e., changes in the Revelle factor) of increasing $p \mathrm{CO}_{2}$ by $40 \mu$ atm during the last 20 years, with the open ocean DIC end-member changed to the respective open ocean carbonate chemistry conditions (see section 2.2 for details). (a) Changes in overall coral reef metabolism, with a $10 \%$ decrease or increase in both photosynthesis and respiration rates; increase; and (c) changes in the balance between photosynthesis $(P)$ and respiration $(R)$, with a decrease or increase in $P / R$ by $10 \%$ in comparison to modern day conditions. Numbers denote the mean $p \mathrm{CO}_{2}$ levels over the entire diel cycle during the different model runs. (b) changes in calcification rate, with a $10 \%$ decrease or

\subsection{Evaluating Potential Drivers of Changes in $p \mathrm{CO}_{2}$}

Based on 1 month of carbonate chemistry observations in a coral reef flat community (Heron Island, GBR) [McMahon et al., 2013] a simple model was developed to evaluate how changes to coral reef metabolic processes affect the diel average of $p \mathrm{CO}_{2}$. Increasing bulk coral reef metabolism (i.e., increases in both photosynthesis $(P)$ and respiration $(R)$ equally) led to an increase in average diel $p \mathrm{CO}_{2}$. Increasing $P$ and $R$ equally by $10 \%$ above current values increased the average $p \mathrm{CO}_{2}$ by $9 \mu$ atm, while decreasing bulk metabolism $10 \%$ below current values decreased the average $p \mathrm{CO}_{2}$ by $8 \mu$ atm (Figure 3a). Changing the calcification rate had a similar effect on $p \mathrm{CO}_{2}$, with a $10 \%$ decrease in calcification decreasing average $p \mathrm{CO}_{2}$ by $11 \mu$ atm and an increase in calcification by $10 \%$ raising the $p \mathrm{CO}_{2}$ by $12 \mu$ atm (Figure $3 \mathrm{~b}$ ). Changes to the ratio of photosynthesis to respiration $(P / R)$ had the greatest effect on average $p \mathrm{CO}_{2}$. A decrease in $P / R$ of $10 \%$ below the current value increased average diel $p \mathrm{CO}_{2}$ by $130 \mu$ atm, while an increase in $P / R$ of $10 \%$ decreased the average $p \mathrm{CO}_{2}$ by $96 \mu$ atm (Figure $3 c$ ).

\section{Discussion}

\subsection{Robustness and Potential Artifacts in the Trend}

Diel metabolic processes in coral reefs [e.g., Schmalz and Swanson, 1969; Shaw et al., 2012] are the largest possible source of carbonate chemistry variation in coral reef ecosystems. Therefore, averaging carbonate chemistry parameters over at least one diel cycle acts to remove this source of variability from the data set. The biogeochemical processes controlling carbonate chemistry in coral reefs can be influenced by physical variables such as currents and light availability [e.g., Marubini et al., 2001; Suzuki and Kawahata, 2003] that vary over daily and seasonal time scales. However, any error introduced from variation in short-term physical drivers such as light availability due to changes in cloud cover would be random and nonsystematic. Any shortterm error of this sort would be expected to conceal or blur any long-term trends in $p \mathrm{CO}_{2}$. Furthermore, using data from various systems, locations, and seasons would tend to create noise but no trend. Therefore, we consider the observed global trend to be robust in spite of any inherent short-term variation in coral reef carbonate chemistry.

To evaluate the potential causes behind this rapid increase in coral reef $p \mathrm{CO}_{2}$, influences of seasonality,

temperature, study length, methodology, and coral reef type were first examined. The majority of seasonal coral reef $\mathrm{PCO}_{2}$ variability is due to temperature effects and changes in community metabolism [Bates, 2002]. Besides a surplus of summer months during 2000-2010, seasons were well distributed throughout the data set (see Table S1 in the supporting information). There was no significant difference in the slope of the linear regression between $p \mathrm{CO}_{2}$ and year since 1992 when all summer months were removed from the analysis or 

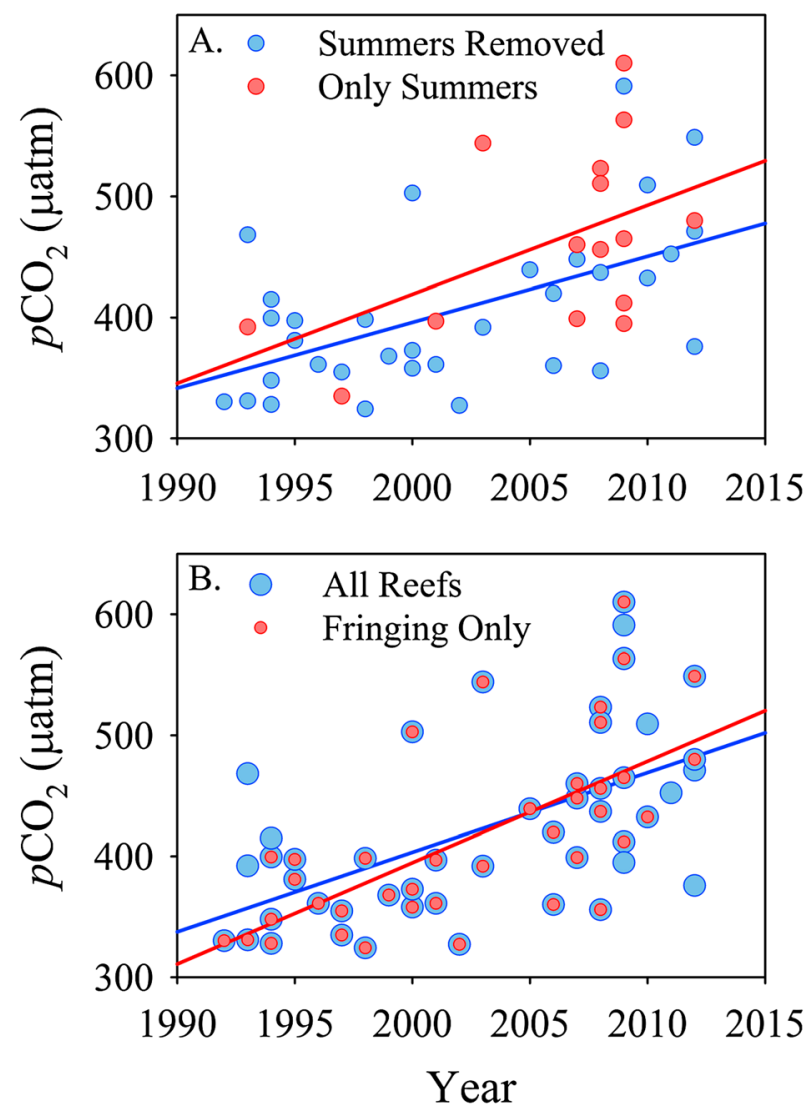

Figure 4. Impacts of potential sources of error in the trend of $p \mathrm{CO}_{2}$ versus year. (a) The trend when only summertime measurements (red) were used and when summertime measurements were removed from the analysis (blue). Differences between the slopes were not statistically significant $(F=0.76$ and $p=0.37)$. (b) Effect of coral reef type on the trend of $p \mathrm{CO}_{2}$ versus year, with all reefs included in the analysis (small red dots) and only fringing reefs included (large blue dots). Differences between the slopes were not statistically significant $(F=0.3$ and $p=0.59$ ). when only summer months were used in the analysis (Figure 4a). Also, when $p \mathrm{CO}_{2}$ was normalized to the mean temperature of the data set $\left(26.4^{\circ} \mathrm{C}\right)$ using the equation from Takahashi et al. [1993] there was no significant difference from the trend in Figure $2 \mathrm{~b}$. Over the past 50 years, an $0.5^{\circ} \mathrm{C}$ increase in the average oceanic temperature can only account for an increase in $\mathrm{pCO}_{2}$ of $\sim 10 \mu$ atm [Sweeney et al., 2002], which is well below the $\sim 170 \mu$ atm increase observed in the mean coral reef $p \mathrm{CO}_{2}$ over the same time period. Therefore, seasonal and long-term temperature variations alone cannot explain the observed increase in coral reef $p \mathrm{CO}_{2}$. There was no significant correlation between the study length and average $p \mathrm{CO}_{2}$, indicating that the length of the studies had no effect on the observed long-term trend. Also, there was no significant difference between the regressions of increasing $p \mathrm{CO}_{2}$ when only measured $p \mathrm{CO}_{2}$ values were used, indicating that the method used to calculate $p \mathrm{CO}_{2}$ from measurements of other carbonate chemistry parameters had no effect on the observed long-term trend.

An analysis of diverse coral reef types demonstrated that coral reef type can influence water column carbonate chemistry parameters [Suzuki and Kawahata, 2003]. Some of the main factors influencing coral reef carbonate chemistry were determined to be proximity to land, terrestrial nutrient inputs, and the residence time of reef water masses. However, the

major determinant of whether or not a reef was a source or sink of $\mathrm{CO}_{2}$ to the atmosphere was a system-level net organic-to-inorganic carbon production ratio $\left(R_{\mathrm{OI}}\right)$ or ratio of net photosynthesis to calcification [Suzuki and Kawahata, 2003]. This agrees well with our model, which showed the largest metabolic influence on average coral reef $p \mathrm{CO}_{2}$ to be changes in the ratio of photosynthesis to respiration (Figure 3).

In order to examine any possible bias of coral reef type in our data set, each reef system was categorized as either fringing, atoll, or fringing-atoll (Table S1 in supporting information). These categories are largely representative of the proximity of each reef to a significant landmass, one of the more important factors shown to control carbonate chemistry by Suzuki and Kawahata [2003]. For example, Kaneohe Bay was categorized as fringing due to the high likelihood of terrestrial inputs, Eniwetok Lagoon was categorized as an atoll due to its relative isolation, and Heron Island was categorized as fringing atoll ( $70 \mathrm{~km}$ from land). While the outer GBR reefs like Heron Island are relatively far from land, they have been shown to accumulate terrestrial-derived contaminants [Burns and Brinkman, 2011]. The vast majority of reefs surveyed since 1992 were fringing reefs and were therefore most likely to experience some terrestrial influences (Table S1 in the supporting information). The trend in the mean $p \mathrm{CO}_{2}$ changes slightly when only fringing reefs were included in the analysis, with the rate of change for $p \mathrm{CO}_{2}$ increasing $\left(6.58 \mu \mathrm{atm} \mathrm{yr}^{-1}\right.$ versus $\left.8.38 \mu \mathrm{atm} \mathrm{yr}^{-1}\right)$, although the difference is not significant (Figure $4 b$ ). This increase may be indicative of land base inputs having a greater influence on fringing reefs and would be expected of reefs that are within closer to proximity to land (discussed in detail later). 
Recent models have demonstrated that a decrease in the buffering capacity of open ocean seawater due to increasing $p \mathrm{CO}_{2}$ could lead to dramatic increases in the diel variability and averages of $p \mathrm{CO}_{2}$ observed in coral reef systems [Jury et al., 2013; Shaw et al., 2013]. This increase in $p \mathrm{CO}_{2}$ variability is largely due to an increase in the Revelle factor as more $\mathrm{CO}_{2}$ is dissolved into the ocean. In order to determine the purely chemical effect of increasing the open ocean Revelle factor, our model was run with an end-member set to the open ocean carbonate chemistry from $\sim 20$ years ago $\left(p \mathrm{CO}_{2}=360 \mu \mathrm{atm}\right.$; Figure 2$)$. The decrease in buffer capacity caused by a $40 \mu$ atm increase in atmospheric $\mathrm{CO}_{2}$ led to an additional $10 \mu$ atm increase in the diel average $p \mathrm{CO}_{2}$ at Heron Island. Thus, the increase in average $p \mathrm{CO}_{2}$ during the last 20 years would have been $\sim 2.5 \mu \mathrm{atm} \mathrm{yr}{ }^{-1}$ instead of $\sim 2 \mu \mathrm{atm} \mathrm{yr}^{-1}$, and while this increase is greater than what would be expected in the open ocean, it cannot explain the global trend observed in coral reefs. Jury et al. [2013] modeled greater increases (up to 2 times the open ocean) in the average $p \mathrm{CO}_{2}$ of a Hawaiian coral reef due to reduced buffering capacity and an increase in seawater residence time. In either case, current changes to the Revelle factor are not great enough to explain the accelerated increase in coral reef $p \mathrm{CO}_{2}$; however, this process will likely become much more important in the coming decades [Shaw et al., 2013].

\subsection{The Influence of Changing Reef Metabolism}

Our model based on Heron Island carbonate chemistry data allows us to quantitatively determine whether realistic changes in coral reef metabolism can explain the observed trend in $p \mathrm{CO}_{2}$. Diel variability in coral reef $p \mathrm{CO}_{2}$ is mainly driven by benthic metabolic processes (i.e., respiration, photosynthesis, calcification, and $\mathrm{CaCO}_{3}$ dissolution), and the diel amplitude is often greater than that of seasonal changes. High calcification rates are thought to be the main reason that coral reefs are sources of $\mathrm{CO}_{2}$ to the atmosphere [Gattuso et al., $1999 \mathrm{~b}]$. Calcification increases $\mathrm{CO}_{2}$ through the uptake of TA, as $\sim 0.6 \mathrm{~mol}$ of $\mathrm{CO}_{2}$ is released for each mole of $\mathrm{CaCO}_{3}$ formed [Frankignoulle et al., 1994]. Coral calcification rates in the GBR have decreased $\sim 10-14 \%$ over the past 50 years [De'ath et al., 2009], and OA is expected to further reduce calcification rates [e.g., Silverman et al., 2009; Shamberger et al., 2011]. The magnitude of this change is similar to that tested in our model (10\%), which resulted in a small decrease in average $p \mathrm{CO}_{2}$ (Figure 3b). Since calcification shifts the carbonate system toward $\mathrm{CO}_{2}$, any reduction in calcification would reduce the mean $p \mathrm{CO}_{2}$, which is opposite to our observations (Figure 2). Therefore, any decreases in the calcification rates of coral reefs over the past 50 years could not possibly have accounted for the observed changes in the mean $p \mathrm{CO}_{2}$.

Primary production and respiration can exert strong control on seawater carbonate chemistry and are thought to be near balanced in coral reef systems due to the rapid turnover and cycling of nutrients and organic matter (OM) [Gattuso et al., 1998]. As photosynthesis and respiration change the dissolved inorganic carbon (DIC) concentrations over the course of a day, increases in $p \mathrm{CO}_{2}$ are greater than decreases due to changes in the Revelle factor (Figure 3) [Suzuki, 1998; Jury et al., 2013; Shaw et al., 2013]. Therefore, the tight coupling of respiration and photosynthesis in coral reefs means that a bulk increase in coral reef metabolism would lead to a higher average $p \mathrm{CO}_{2}$ and lower average $\mathrm{pH}$. Any changes in the ratio of production to respiration $(P / R)$ could also lead to changes in the average $p \mathrm{CO}_{2}$ of coral reefs. Interestingly, increases in global ocean temperatures could preferentially stimulate respiration over photosynthesis [Brown et al., 2004; Harris et al., 2006]. If this occurs in coral reefs, it would act to raise the mean $p \mathrm{CO}_{2}$ even quicker than stimulating both photosynthesis and respiration equally (Figure 3). The changes in the observed $p \mathrm{CO}_{2}$ are similar in magnitude to the changes in $p \mathrm{CO}_{2}$ derived from changes to coral reef metabolic processes (particularly the ratio of $P / R$ ) projected by our model (Figures 2 and 3 ). Therefore, realistic changes to the metabolic balance of coral reefs have the potential to significantly affect the average $p \mathrm{CO}_{2}$, resulting in an increase in $p \mathrm{CO}_{2}$ equal or greater in magnitude to increases due to changing atmospheric $\mathrm{CO}_{2}$.

\subsection{Potential Drivers of Changes to Coral Reef Metabolism}

Our model demonstrates that relatively modest changes in coral reef metabolism could account for the rapid increase in average coral reef $\mathrm{pCO}_{2}$. However, have there been anthropogenic drivers that could have caused changes in community metabolism over the past 50 years? Terrestrial-derived sediment, nutrient, and OM inputs represent some of the major anthropogenic pressures on coral reef ecosystems [Hughes et al., 2003; Pandolfi et al., 2003]. A significant human alteration of the global nitrogen and phosphorus cycles [Rockström et al., 2009] now delivers excess nutrients to coral reefs via surface runoff, submarine groundwater discharge, and atmospheric deposition [Fabricius, 2005]. Due to the tight coupling of photosynthesis and respiration, 
increased nutrient loading to coral reefs could lead to higher average $p \mathrm{CO}_{2}$ levels by stimulating overall coral reef metabolism. Also, increased OM inputs in the form of particulate and dissolved organic matter could lower the $P / R$ ratio of reefs and increase the average $p \mathrm{CO}_{2}$ even more dramatically than changing the bulk metabolism. In fact, the input of terrestrial-derived $\mathrm{OM}$ was associated with elevated $p \mathrm{CO}_{2}$ within the GBR lagoon [Suzuki et al., 2001]. Therefore, it is possible that anthropogenic inputs of nutrients and OM along with impacts to watershed processes (e.g., increased runoff) could drive changes in coral reef metabolism leading to increases in the average $p \mathrm{CO}_{2}$ of coral reefs.

An example of high $p \mathrm{CO}_{2}$ associated with terrestrial inputs was observed in a coral reef lagoon in the Cook Islands, where submarine groundwater discharge was a major driver of $p \mathrm{CO}_{2}$ dynamics [Cyronak et al., 2014]. Kaneohe Bay, Hawaii, has some of the highest average $p \mathrm{CO}_{2}$ values reported in worldwide coral reefs (see Table S1 in the supporting information) and is considered to have large inputs of terrestrial nutrients and OM [Ringuet and Mackenzie, 2005; Drupp et al., 2011]. The high average $p \mathrm{CO}_{2}$ in Kaneohe Bay may be indicative of high rates of OM remineralization and the intimate connection between coral reef primary productivity and respiration. Reef metabolism at Kaneohe Bay has also been shown to be net heterotrophic, which corresponds to a $P / R$ ratio below 1 [Shamberger et al., 2011]. The $P / R$ of coral reefs may be highly dependent on the production and storage of OM. For example, the input of nutrients from sewage discharge resulted in pelagic algal blooms in Kaneohe Bay between 1960 and 1970 [Smith et al., 1981]. The pelagic blooms subsided soon after the sewage discharge ceased; however, macroalgae abundance remained elevated due to nutrients stored in sediments [Szmant, 2002]. The eutrophication of Kaneohe Bay may offer insights into the long-term storage of $\mathrm{OM}$ in the sediments of reef habitats and subsequent remineralization and export of $\mathrm{CO}_{2}$ to the water column.

Episodic events such as bleaching and storms can also have a significant influence on the $p \mathrm{CO}_{2}$ of coral reef ecosystems by disturbing the reef's metabolic balance. Bleaching-induced stress and respiration were associated with an $\sim 50 \mu$ atm increase in the average $p \mathrm{CO}_{2}$ of a coral reef, most likely due to the release of high amounts of OM [Kayanne et al., 2005]. Tropical cyclones have also been shown to increase coral reef $p \mathrm{CO}_{2}$ over short time scales through increased terrestrial runoff, increases in respiration, and habitat destruction [Gray et al., 2012; Manzello et al., 2013]. Therefore, increases in bleaching [Hoegh-Guldberg et al., 2007] and tropical cyclones [Holland and Webster, 2007] over the last 50 years could have contributed to the increasing average $p \mathrm{CO}_{2}$ of coral reefs. In addition, the historical overfishing of coral reefs is thought to have shifted community structure through the loss of herbivores and the proliferation of crown of thorns starfish, which may impact the inorganic carbon biogeochemistry of coral reef ecosystems [Jackson et al., 2001].

\subsection{Conclusions}

In summary, we detected an overarching trend of increasing coral reef $p \mathrm{CO}_{2}$ over the past 50 years, with an accelerated increase over the last 20 years. This accelerated increase is most likely explained by a combination of disturbances to the metabolic balance of coral reef ecosystems. These disturbances include anthropogenic perturbations to natural drivers of $\mathrm{pCO}_{2}$ such as nutrient and OM loading, habitat degradation through intensified storms, bleaching, overfishing, and anthropogenic climate forcings. In coral reefs regional disturbances to drivers of seawater carbonate chemistry may be equally as important as increasing atmospheric $\mathrm{CO}_{2}$ in raising the average diel $p \mathrm{CO}_{2}$. This trend may also apply to other coastal ecosystems which are known sources of $\mathrm{CO}_{2}$ to the atmosphere such as estuaries. Therefore, combating the acidification of coral reefs may require not only reducing global $\mathrm{CO}_{2}$ emissions, but also managing the regional biogeochemical perturbations (e.g., nutrient and OM loading) of carbonate chemistry in individual systems.

Acknowledgments

We thank Ashly McMahon for his invaluable work in the field. Data supporting Figures 2 and 4 are available in Table S1 in the supporting information. This work was funded through the Australian Research Council linkage (LP100200732) and discovery (DP110103638) grants.

The Editor thanks two anonymous reviewers for their assistance in evaluating this paper.

\section{References}

Andersson, A. J., K. L. Yeakel, N. R. Bates, and S. J. de Putron (2013), Partial offsets in ocean acidification from changing coral reef biogeochemistry, Nat. Clim. Change, doi:10.1038/NCLIMATE2050.

Anthony, K., J. A. Kleypas, and J. P. Gattuso (2011), Coral reefs modify their seawater carbon chemistry-implications for impacts of ocean acidification, Global Change Biol., doi:10.1111/j.1365-2486.2011.02530.x.

Bates, N. R. (2002), Seasonal variability of the effect of coral reefs on seawater $\mathrm{CO}_{2}$ and air-sea $\mathrm{CO}_{2}$ exchange, Limnol. Oceanogr., $47(1)$, $43-52$. Bates, N. R., and A. G. Dickson (2012), Detecting anthropogenic carbon dioxide uptake and ocean acidification in the North Atlantic Ocean, Biogeosciences, 9, 2509-2522, doi:10.5194/bg-9-2509-2012.

Bates, N., Y. Astor, M. Church, K. Currie, J. Dore, M. Gonaález-Dávila, L. Lorenzoni, F. Muller-Karger, J. Olafsson, and M. Santa-Casiano (2014), A timeseries view of changing ocean chemistry due to ocean uptake of anthropogenic $\mathrm{CO}_{2}$ and ocean acidification, Oceanography, 27(1), 126-141. Brown, J. H., J. F. Gillooly, A. P. Allen, V. M. Savage, and G. B. West (2004), Toward a metabolic theory of ecology, Ecology, 85(7), $1771-1789$. 
Burns, K., and D. Brinkman (2011), Organic biomarkers to describe the major carbon inputs and cycling of organic matter in the central Great Barrier Reef region, Estuarine Coastal Shelf Sci., 93(2), 132-141.

Cyronak, T., I. R. Santos, D. V. Erler, D. T. Maher, and B. D. Eyre (2014), Drivers of $p \mathrm{CO}_{2}$ variability in two contrasting coral reef lagoons: The influence of submarine groundwater discharge, Global Biogeochem. Cycles, 28, 398-414, doi:10.1002/2013GB004598.

De'ath, G., J. M. Lough, and K. E. Fabricius (2009), Declining coral calcification on the Great Barrier Reef, Science, 323(5910), 116-119, doi:10.1126/science.1165283.

Doney, S. C., V. J. Fabry, R. A. Feely, and J. A. Kleypas (2009), Ocean acidification: The other $\mathrm{CO}_{2}$ problem, Annu. Rev. Mar. Sci., 1, 169-192.

Drupp, P., E. H. De Carlo, F. T. Mackenzie, P. Bienfang, and C. L. Sabine (2011), Nutrient inputs, phytoplankton response, and $\mathrm{CO}_{2}$ variations in a semi-enclosed subtropical embayment, Kaneohe Bay, Hawaii, Aquat. Geochem., 17(4-5), 473-498.

Duarte, C. M., I. E. Hendriks, T. S. Moore, Y. S. Olsen, A. Steckbauer, L. Ramajo, J. Carstensen, J. A. Trotter, and M. McCulloch (2013), Is ocean acidification an open-ocean syndrome? Understanding anthropogenic impacts on seawater pH, Estuaries Coasts, 36, 221-236.

Fabricius, K. E. (2005), Effects of terrestrial runoff on the ecology of corals and coral reefs: Review and synthesis, Mar. Pollut. Bull., 50(2), 125-146.

Frankignoulle, M., C. Canon, and J.-P. Gattuso (1994), Marine calcification as a source of carbon dioxide: Positive feedback of increasing atmospheric $\mathrm{CO}_{2}$, Limnol. Oceanogr., 39(2), 458-462.

Friedrich, T., et al. (2012), Detecting regional anthropogenic trends in ocean acidification against natural variability, Nat. Clim. Change, 2(3), 167-171. [Available at http://www.nature.com/nclimate/journal/vaop/ncurrent/abs/nclimate1372.html\#supplementary-information.]

Gattuso, J. P., M. Frankignoulle, and R. Wollast (1998), Carbon and carbonate metabolism in coastal aquatic ecosystems, Annu. Rev. Ecol. Syst., $29,405-434$.

Gattuso, J.-P., D. Allemand, and M. Frankignoulle (1999a), Photosynthesis and calcification at cellular, organismal and community levels in coral reefs: A review on interactions and control by carbonate chemistry, Am. Zool., 39(1), 160-183, doi:10.1093/icb/39.1.160.

Gattuso, J.P., M. Frankignoulle, and S. V. Smith (1999b), Measurement of community metabolism and significance in the coral reef $\mathrm{CO}_{2}$ source-sink debate, Proc. Natl. Acad. Sci. U.S.A., 96(23), 13,017-13,022, doi:10.1073/pnas.96.23.13017.

Gray, S. E. C., M. D. DeGrandpre, C. Langdon, and J. E. Corredor (2012), Short-term and seasonal pH, $p \mathrm{CO}_{2}$ and saturation state variability in a coral-reef ecosystem, Global Biogeochem. Cycles, 26, GB3012, doi:10.1029/2011GB004114.

Halpern, B. S., et al. (2008), A global map of human impact on marine ecosystems, Science, 319(5865), 948-952, doi:10.1126/science.1149345.

Harris, L. A., C. M. Duarte, and S. W. Nixon (2006), Allometric laws and prediction in estuarine and coastal ecology, Estuaries Coasts, 29(2), $340-344$.

Hoegh-Guldberg, O., et al. (2007), Coral reefs under rapid climate change and ocean acidification, Science, 318(5857), 1737-1742, doi:10.1126/science.1152509.

Holland, G. J., and P. J. Webster (2007), Heightened tropical cyclone activity in the north atlantic: Natural variability or climate trend?, Philos. Trans. R. Soc., A, 365(1860), 2695-2716, doi:10.1098/rsta.2007.2083.

Hughes, T. P., A. H. Baird, D. R. Bellwood, M. Card, S. R. Connolly, C. Folke, R. Grosberg, O. Hoegh-Guldberg, J. Jackson, and J. Kleypas (2003), Climate change, human impacts, and the resilience of coral reefs, Science, 301(5635), 929-933.

Jackson, J. B. C., et al. (2001), Historical overfishing and the recent collapse of coastal ecosystems, Science, 293(5530), 629-637, doi:10.1126/ science.1059199.

Jury, C., F. Thomas, M. Atkinson, and R. Toonen (2013), Buffer capacity, ecosystem feedbacks, and seawater chemistry under global change, Water, 5(3), 1303-1325.

Kayanne, H., A. Suzuki, and H. Saito (1995), Diurnal changes in the partial pressure of carbon dioxide in coral reef water, Science, 269(5221), 214-216.

Kayanne, H., H. Hata, S. Kudo, H. Yamano, A. Watanabe, Y. Ikeda, K. Nozaki, K. Kato, A. Negishi, and H. Saito (2005), Seasonal and bleachinginduced changes in coral reef metabolism and $\mathrm{CO}_{2}$ flux, Global Biogeochem. Cycles, 19, GB3015, doi:10.1029/2004GB002400.

Keeling, C. D., S. C. Piper, R. B. Bacastow, M. Wahlen, T. P. Whorf, M. Heimann, and H. A. Meijer (2001), Exchanges of Atmospheric $\mathrm{CO}_{2}$ and ${ }^{13} \mathrm{CO}_{2}$ With the Terrestrial Biosphere and Oceans From 1978 to 2000, Global aspects, SIO Ref. Ser., No. 01-06, pp. 88, Scripps Institution of Oceanography, San Diego, Calif.

Lueker, T. J., A. G. Dickson, and C. D. Keeling (2000), Ocean $p \mathrm{CO}_{2}$ calculated from dissolved inorganic carbon, alkalinity, and equations for $\mathrm{K} 1$ and K2: Validation based on laboratory measurements of $\mathrm{CO}_{2}$ in gas and seawater at equilibrium, Mar. Chem., 70, 105-119.

Manzello, D., I. Enochs, S. Musielewicz, R. Carlton, and D. Gledhill (2013), Tropical cyclones cause $\mathrm{CaCO}_{3}$ undersaturation of coral reef seawater in a high- $\mathrm{CO}_{2}$ world, J. Geophys. Res. Oceans, 118, 5312-5321, doi:10.1002/jgrc.20378.

Marubini, F., H. Barnett, C. Langdon, and M. Atkinson (2001), Dependence of calcification on light and carbonate ion concentration for the hermatypic coral Porites compressa, Mar. Ecol. Prog. Ser., 220, 153-162.

McMahon, A., I. R. Santos, T. Cyronak, and B. D. Eyre (2013), Hysteresis between coral reef calcification and the seawater aragonite saturation state, Geophys. Res. Lett., 40, 4675-4679, doi:10.1002/grl.50802.

Mehrbach, C., C. Culberson, J. Hawley, and R. Pytkowicz (1973), Measurement of the apparent dissociation constants of carbonic acid in seawater at atmospheric pressure, Limnol. Oceanogr., 18(6), 897-907.

Pandolf, J. M., R. H. Bradbury, E. Sala, T. P. Hughes, K. A. Bjorndal, R. G. Cooke, D. McArdle, L. McClenachan, M. J. Newman, and G. Paredes (2003), Global trajectories of the long-term decline of coral reef ecosystems, Science, 301(5635), 955-958.

Ringuet, S., and F. T. Mackenzie (2005), Controls on nutrient and phytoplankton dynamics during normal flow and storm runoff conditions, southern Kaneohe Bay, Hawaii, Estuaries, 28(3), 327-337.

Rockström, J., W. Steffen, K. Noone, Å. Persson, F. S. Chapin, E. F. Lambin, T. M. Lenton, M. Scheffer, C. Folke, and H. J. Schellnhuber (2009), A safe operating space for humanity, Nature, 461(7263), 472-475.

Schmalz, R. F., and F. J. Swanson (1969), Diurnal variations in the carbonate saturation of seawater, J. Sediment. Res., 39(1), 255-267.

Shamberger, K. E. F., R. A. Feely, C. L. Sabine, M. J. Atkinson, E. H. DeCarlo, F. T. Mackenzie, P. S. Drupp, and D. A. Butterfield (2011), Calcification and organic production on a Hawaiian coral reef, Mar. Chem., 127, 64-75, doi:10.1016/j.marchem.2011.08.003.

Shampine, L. F., and M. W. Reichelt (1997), The matlab ODE suite, SIAM J. Sci. Comput., 18, 1-22.

Shaw, E. C., B. I. McNeil, and B. Tilbrook (2012), Impacts of ocean acidification in naturally variable coral reef flat ecosystems, J. Geophys. Res., 117, C03038, doi:10.1029/2011JC007655

Shaw, E. C., B. I. McNeil, B. Tilbrook, R. Matear, and M. L. Bates (2013), Anthropogenic changes to seawater buffer capacity combined with natural reef metabolism induce extreme future coral reef $\mathrm{CO}_{2}$ conditions, Global Change Biol., 19(5), 1632-1641, doi:10.1111/gcb.12154.

Silverman, J., B. Lazar, and J. Erez (2007), Effect of aragonite saturation, temperature, and nutrients on the community calcification rate of a coral reef, J. Geophys. Res., 112, C05004, doi:10.1029/2006JC003770.

Silverman, J., B. Lazar, L. Cao, K. Caldeira, and J. Erez (2009), Coral reefs may start dissolving when atmospheric $\mathrm{CO}_{2}$ doubles, Geophys. Res. Lett., 36, L05606, doi:10.1029/2008GL036282. 
Silverman, J., D. I. Kline, L. Johnson, T. Rivlin, K. Schneider, J. Erez, B. Lazar, and K. Caldeira (2012), Carbon turnover rates in the One Tree Island reef: A 40-year perspective, J. Geophys. Res., 117, G03023, doi:10.1029/2012JG001974.

Smith, S. V., W. J. Kimmerer, E. A. Laws, R. Brock, and T. W. Walsh (1981), Kaneohe Bay sewage diversion experiment: Perspectives on ecosystem responses to nutritional perturbation, Pac. Sci, 35(4), 279-395.

Suzuki, A. (1998), Combined effects of photosynthesis and calcification on the partial pressure of carbon dioxide in seawater, J. Oceanogr., $54(1), 1-7$.

Suzuki, A., and H. Kawahata (2003), Carbon budget of coral reef systems: An overview of observations in fringing reefs, barrier reefs and atolls in the Indo-Pacific regions, Tellus $B, 55(2), 428-444$.

Suzuki, A., H. Kawahata, T. Ayukai, and K. Goto (2001), The oceanic $\mathrm{CO}_{2}$ system and carbon budget in the Great Barrier Reef, Australia, Geophys. Res. Lett., 28(7), 1243-1246, doi:10.1029/2000GL011875.

Sweeney, C., T. Takahashi, A. Gnanadesikan, R. Wanninkhof, R. A. Feely, G. Friedrich, F. Chavez, N. Bates, J. Olafsson, and J. Sarmiento (2002), Spatial and temporal variability of surface water $p \mathrm{CO}_{2}$ and sampling strategies, in A Large-Scale $\mathrm{CO}_{2}$ Observing Plan: In Situ Oceans and Atmosphere (LSCOP), pp. 155-175, U.S. Department of Commerce, National Oceanic and Atmospheric Administration, Springfield, Va. Szmant, A. M. (2002), Nutrient enrichment on coral reefs: Is it a major cause of coral reef decline?, Estuaries, 25(4), 743-766.

Takahashi, T., J. Olafsson, J. G. Goddard, D. W. Chipman, and S. Sutherland (1993), Seasonal variation of $\mathrm{CO}_{2}$ and nutrients in the high-latitude surface oceans: A comparative study, Global Biogeochem. Cycles, 7(4), 843-878, doi:10.1029/93GB02263. 